\title{
Papers
}

\section{Risk of testicular cancer in men with abnormal semen characteristics: cohort study}

\author{
Rune Jacobsen, Erik Bostofte, Gerda Engholm, Johnni Hansen, Jørgen H Olsen, Niels E Skakkebæk, \\ Henrik Møller
}

\begin{abstract}
Objective To explore the associations between semen characteristics and subsequent risk of testicular cancer.

Design Cohort study.

Participants 32442 men who had a semen analysis done at the Sperm Analysis Laboratory in Copenhagen during 1963-95.

Main outcome measure Standardised incidence ratios of testicular cancer compared with total population of Danish men.

Results Men in couples with fertility problems were more likely to develop testicular cancer than other men (89 cases, standardised incidence ratio 1.6; 95\% confidence interval 1.3 to 1.9$)$. The risk was relatively constant with increasing time between semen analysis and cancer diagnosis. Analysis according to specific semen characteristics showed that low semen concentration (standardised incidence ratio 2.3), poor motility of the spermatozoa (2.5), and high proportion of morphologically abnormal spermatozoa (3.0) were all associated with an increased risk of testicular cancer. The only other cancer group that showed increased incidence was "peritoneum and other digestive organs" (six cases; 3.7, 1.3 to 8.0). Of these, two cases were probably and two cases were possibly extragonadal germ cell tumours.

Conclusions The results point towards the existence of common aetiological factors for low semen quality and testicular cancer. Low semen quality may also be associated with increased incidence of extragonadal germ cell tumours.
\end{abstract}

\section{Introduction}

Over recent decades a possible decrease in semen quality $^{12}$ and an increase in the incidence of testicular cancer have been reported in many populations. ${ }^{3-5}$ It is unclear whether these temporal trends are independent phenomena or somehow connected to each other. ${ }^{6-8}$ Case-control studies on subfertility and subsequent risk of testicular cancer have given conflicting results. ${ }^{89}$ However, a recent Danish population based cohort study found an increased risk of testicular cancer in men with few children for their age. ${ }^{10}$ These findings supported the results of an earlier Danish case-control study. ${ }^{8}$ Both of these Danish studies used the number of children fathered at a given age as the measure of fertility. Thus some men with normal reproductive potential will inevitably have been classified as having low relative fertility because they had no or few children for reasons that were unrelated to their fertility. Subfertility can be measured more directly by analysis of semen for characteristics such as spermatocyte concentration, motility, and morphology. ${ }^{11} 12$

Men with testicular cancer often have abnormal semen characteristics, ${ }^{13} 14$ but the association between abnormal semen characteristics and testicular cancer has not been investigated prospectively. We studied the incidence of testicular cancer in relation to semen characteristics in 32442 men who had semen analysis at the Sperm Analysis Laboratory in Copenhagen during 1963-95.

\section{Participants and methods}

We linked information on all men in couples with fertility problems who had a semen analysis done at the Sperm Analysis Laboratory in Copenhagen during 1963-95 ( $\mathrm{n}=32$ 442) with data in the Danish Cancer Registry, which holds information on all cases of cancer in the Danish population from 1943 to $1995 .{ }^{15}$ Men who visited the laboratory for other reasons (such as semen analysis after vasectomy) were excluded from the analysis. The Copenhagen laboratory is one of several public semen analysis laboratories in Denmark and examines semen samples mostly from men in the area of Copenhagen. Men are referred to the clinic by general practitioners and urologists, and the investigations are paid for through the public health system. Men with cancer before the date of semen analysis were excluded. For men who had multiple semen tests only their first test was used in the analysis. Similarly, only the first cancer diagnosis in a given man was included in the analysis. The methods used for analysis of semen (sperm concentration and motility and proportion of morphologically abnormal spermatozoa) have been described previously. ${ }^{16}$ For each man we also obtained information on date of birth, dates of birth of his children, and date of death from the Central Population Register and the National Death Register.

We calculated the expected numbers of cancer cases in the cohort (by multiplying years at risk with primary cancer rates in the Danish population) and

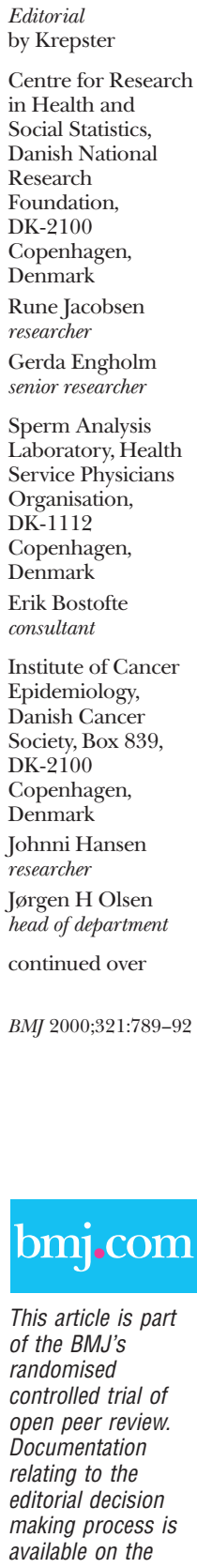

BMJ 2000;321:789-92

This article is part of the BMJ's randomised controlled trial of open peer review. Documentation relating to the editorial decision making process is available on the BMJ's website 
Department of Growth and Reproduction,

National University

Hospital, DK-2100

Copenhagen,

Denmark

Niels E Skakkebæk

professor

Thames Cancer

Registry, Guy's,

King's, and

St Thomas' School

of Medicine,

London SE1 3QD

Henrik Møller

professor

Correspondence to:

Rune Jacobsen,

Department of

Epidemiology,

Institute of Public

Health, Faculty of

Health Sciences,

University of

Copenhagen,

Panum Institute,

DK-2200

Copenhagen,

Denmark

R.jacobsen@

pubhealth.ku.dk
Table 1 Standardised incidence ratios and 95\% confidence intervals for different cancers in cohort of 32442 men having sperm analysis in Copenhagen, 1963-95

\begin{tabular}{lrrr} 
Type of cancer & $\begin{array}{c}\text { Observed } \\
\text { No of } \\
\text { cases }\end{array}$ & $\begin{array}{r}\text { Expected } \\
\text { No of } \\
\text { cases }\end{array}$ & $\begin{array}{c}\text { Standardised } \\
\text { incidence ratio } \\
\text { (95\% Cl) }\end{array}$ \\
\hline \begin{tabular}{l} 
All malignant neoplasms \\
\hline $\begin{array}{l}\text { Peritoneum and other digestive } \\
\text { organs }\end{array}$
\end{tabular} & 681 & 452.6 & $1.1(1.0$ to 1.2$)$ \\
\hline $\begin{array}{l}\text { Testis } \\
\text { Others }\end{array}$ & 89 & 57.1 & $1.6(1.3 \text { to } 1.9)^{*}$ \\
\hline${ }^{*} \mathrm{P}<0.05$. & 386 & 393.3 & $1.0(0.9$ to 1.1$)$ \\
\hline
\end{tabular}

standardised incidence ratios and 95\% confidence intervals using a Fortran computer program. ${ }^{17}$ The standardised incidence ratios were calculated for each type of cancer by time since first semen analysis, stratifying by semen characteristics according to standard definitions of subfertility. ${ }^{12}$ The group of azoospermic men was divided into those with and without children in order to address the possibility that some azoospermic men had not given information on sterilisation or other circumstances resulting in a sudden azoospermia. To examine the separate and joint effects of the three semen characteristics, the cohort was stratified into groups according to their combination of semen measures.

\section{Results}

Overall, the cohort members had an increased risk of testicular cancer and of cancers of the peritoneum and other digestive organs (table 1). Risk of other types of cancer was not increased in the cohort. Eighty nine men developed testicular cancer, giving a standardised incidence ratio of $1.6(95 \%$ confidence interval 1.3 to 1.9). Of these 89 men, 50 had seminomas (standardised incidence ratio $1.5,1.1$ to 1.9$), 37$ had non-seminomas $(1.8,1.2$ to 2.4), and two were unspecified. For cancer of the peritoneum and other digestive organs the standardised incidence ratio was 3.7 (1.3 to 8.0) based on six observed cases. The standardised incidence ratio for cancers of all other sites combined was 1.0 (0.9 to 1.1).

Table 2 shows the standardised incidence ratios for testicular cancer stratified by time between first semen analysis and cancer diagnosis. The highest risk of testicular cancer was in the first two years after the first semen analysis (standardised incidence ratio 1.8). The risk was 1.5-1.6 for two to 11 years after the first semen analysis and 1.3 for more than 11 years since first semen analysis. The trend in the standardised incidence ratios over the four periods of follow up was not significant $(\mathrm{P}=0.46)$.

Table 2 Standardised incidence ratios and 95\% confidence intervals for testicular cancer, stratified by time since semen analysis

\begin{tabular}{lccc}
$\begin{array}{l}\text { Time between semen } \\
\text { analysis and diagnosis } \\
\text { (years) }\end{array}$ & $\begin{array}{c}\text { Observed No } \\
\text { of cases }\end{array}$ & $\begin{array}{c}\text { Expected No } \\
\text { of cases }\end{array}$ & $\begin{array}{c}\text { Standardised } \\
\text { incidence ratio } \\
\text { (95\% Cl) }\end{array}$ \\
\hline $0-2$ & 23 & 12.8 & $1.8(1.1 \text { to } 2.7)^{*}$ \\
\hline-6 & 30 & 20.1 & $1.5(1.0 \text { to } 2.1)^{*}$ \\
\hline-11 & 24 & 15.3 & $1.6(1.0 \text { to } 2.3)^{*}$ \\
\hline$>11$ & 12 & 9.0 & $1.3(0.7$ to 2.3$)$ \\
\hline Trend & & & $\mathrm{P}=0.46$ \\
\hline${ }^{*} \mathrm{P}<0.05$ & & &
\end{tabular}

Table 3 shows the standardised incidence ratios of testicular cancer, stratified by measures of semen quality. In univariate analyses, low semen concentration, poor semen mobility, and a high proportion of abnormal spermatozoa were all associated with increased standardised incidence ratios, whereas the groups with normal semen characteristics had standardised incidence ratios closer to unity. The azoospermic men who had fathered children before semen analysis showed lower risk of testicular cancer than azoospermic men without children (standardised incidence ratio $2.0 v$ 5.3). Men who were not azoospermic but who had sperm concentrations of $20 \mathrm{million} / \mathrm{ml}$ or lower had a higher risk of testicular cancer than men with concentrations above 20 million/ml (standardised incidence ratio $2.3 v 1.1$ ).

Table 3 Standardised incidence ratios and 95\% confidence intervals for testicular cancer according to semen characteristics

\begin{tabular}{|c|c|c|c|c|}
\hline ariable & $\begin{array}{l}\text { Total } \\
\text { No of } \\
\text { men }\end{array}$ & $\begin{array}{l}\text { Observed } \\
\text { No of } \\
\text { cases }\end{array}$ & $\begin{array}{l}\text { Expected } \\
\text { No of } \\
\text { cases }\end{array}$ & $\begin{array}{c}\text { Standardised } \\
\text { incidence ratio } \\
(95 \% \mathrm{Cl})\end{array}$ \\
\hline \multicolumn{5}{|l|}{ Concentration $\left(10^{6} / \mathrm{ml}\right)$} \\
\hline $\begin{array}{l}0 \text { and no children before } \\
\text { analysis }\end{array}$ & 1031 & 7 & 2.0 & $3.5(1.4 \text { to } 7.2)^{x}$ \\
\hline $\begin{array}{l}0 \text { and children before } \\
\text { analysis }\end{array}$ & 1644 & 6 & 3.0 & $2.0(0.7$ to 4.3$)$ \\
\hline $0-20$ & 10509 & 33 & 14.4 & $2.3(1.6$ to 3.2$)$ \\
\hline$>20$ & 18668 & 42 & 36.9 & $1.1(0.8$ to 1.5$)$ \\
\hline Not available & 590 & 1 & 0.8 & $1.3(0.0$ to 7.0$)$ \\
\hline \multicolumn{5}{|l|}{ Motility† } \\
\hline Poor & 1312 & 7 & 2.8 & $2.5(1.0 \text { to } 5.2)^{*}$ \\
\hline Good & 19362 & 44 & 28.0 & $1.6(1.1 \text { to } 2.1)^{x}$ \\
\hline Not available & 9093 & 25 & 21.3 & 1.2 (0.8 to 1.7$)$ \\
\hline \multicolumn{5}{|l|}{ Proportion abnormal (\%)† } \\
\hline$>75$ & 528 & 4 & 1.4 & $3.0(0.8$ to 7.6$)$ \\
\hline $0-75$ & 27618 & 64 & 47.8 & $1.3(1.0$ to 1.7$)$ \\
\hline Not available & 1621 & 8 & 2.9 & $2.7(1.2 \text { to } 5.4)^{*}$ \\
\hline
\end{tabular}

${ }^{*} \mathrm{P}<0.05$. $†$ Excluding 2675 azoospermic men.

The univariate, separate, and joint effects of the three semen quality measures were analysed in the subgroup of 29177 men who had some spermatozoa in the semen sample (table 4). The separate effect of low concentration on the risk of testicular cancer was roughly the same as the univariate effect (standardised incidence ratio 2.1 and 2.3, respectively). Of 10509 men with low semen concentration, 9187 had low concentration as the only abnormal characteristic. Very few men had poor motility only or a high proportion of abnormal spermatozoa only, and no case of testicular cancer was observed in these groups. We therefore could not identify a separate effect of poor motility or of having a high proportion of abnormal spermatozoa. However, the risk of testicular cancer increased with increasing number of subfertility measures present. The standardised incidence ratio was 1.9 for one subfertility measure, 2.7 for two measures, and 9.3 for all three subfertility measures.

Table 5 gives the details of the six cases of cancer in the peritoneum and other digestive organs. Case 1 may have had a testicular cancer before his leukaemia, which probably was treatment induced. An extragonadal germ cell tumour is also possible for case 2, who had increased concentrations of tumour markers. The notifications suggest that cases 3 and 5 had extragonadal germ cell tumours. Cases 4 and 6 seemed unlikely to have had extragonadal germ cell cancers. 
Table 4 Separate and joint effects of three semen quality measures on risk of testicular cancer among 29177 men with some spermatozoa in semen

\begin{tabular}{|c|c|c|c|c|}
\hline Variable & $\begin{array}{c}\text { Total } \\
\text { No of } \\
\text { men }\end{array}$ & $\begin{array}{c}\text { Observed } \\
\text { No of } \\
\text { cases }\end{array}$ & $\begin{array}{l}\text { Expected } \\
\text { No of } \\
\text { cases }\end{array}$ & $\begin{array}{c}\text { Standardised } \\
\text { incidence ratio } \\
(95 \% \mathrm{Cl})\end{array}$ \\
\hline \multicolumn{5}{|l|}{ Univariate effects } \\
\hline $\begin{array}{l}\text { Low concentration } \\
\quad\left(\leqslant 20 \times 10^{6} / \mathrm{ml}\right)\end{array}$ & 10509 & 33 & 14.5 & $2.3(1.6 \text { to } 3.2)^{*}$ \\
\hline Poor motility & 1298 & 7 & 2.8 & $2.5(1.0 \text { to } 5.2)^{\star}$ \\
\hline Many abnormal (>75\%) & 528 & 4 & 1.4 & $3.0(0.8$ to 7.6$)$ \\
\hline \multicolumn{5}{|l|}{ Separate effects } \\
\hline Low concentration (only) & 9187 & 24 & 11.6 & $2.1(1.3 \text { to } 3.1)^{*}$ \\
\hline Low motility (only) & 187 & 0 & 0.4 & - \\
\hline Many abnormal (only) & 213 & 0 & 0.6 & - \\
\hline Other & 19590 & 52 & 39.5 & $1.3(1.0$ to 1.7$)$ \\
\hline \multicolumn{5}{|l|}{ Joint effects } \\
\hline One subfertility measure & 9587 & 24 & 12.6 & $1.9(1.2 \text { to } 2.8)^{*}$ \\
\hline Two subfertility measures & 1251 & 7 & 2.6 & $2.7(1.1 \text { to } 5.5)^{*}$ \\
\hline Three subfertility measures & 82 & 2 & 0.2 & $9.3(1.0$ to 33.4$)$ \\
\hline Other & 18257 & 43 & 36.7 & $1.2(0.9$ to 1.6$)$ \\
\hline
\end{tabular}

${ }^{*} \mathrm{P}<0.05$.

\section{Discussion}

Our retrospective cohort study, based on more than 30000 men in infertile couples, found a strong association between subfertility and subsequent risk of testicular cancer. All men of couples with fertility problems were 1.6 times more likely to develop testicular cancer than the Danish male population in general, and the increase was evident for both seminoma and non-seminoma. The overall analysis included some fully fertile men from couples in which only the woman was subfertile, and the observed higher risk of testicular cancer in the cohort overall would be even higher if only subfertile men were included. Men in the cohort with abnormal semen characteristics had a twofold to threefold increased risk. Our findings are consistent with the results of investigations into spermatogenesis in patients with unilateral testicular cancer ${ }^{18}$ and risk of testicular cancer in men considered subfertile on the basis of a low number of children for their age. ${ }^{8} 10$

The observation that men with unilateral testicular cancer have impaired spermatogenesis ${ }^{18}$ does not preclude the possibility that impaired reproductive capacity is secondary to the cancer. We found that the risk of testicular cancer was relatively constant with increasing time since semen analysis. Impaired spermatogenesis may therefore have been present many years before testicular cancer was diagnosed, pointing towards a permanent state of impaired spermatogenesis.

Our use of semen characteristics to assess subfertility eliminates the misclassification problems in studies based on numbers of children, where men with normal reproductive potential who have no or few children for other reasons may bias the result towards unity. All together, the available data point towards the existence of common risk factors for impaired spermatogenesis and testicular cancer.

Some evidence suggests that testicular cancer has its origin in fetal life. Incidence of testicular cancer is lower among men born during the second world war than men born before and after the war in Denmark, Norway, and Sweden. ${ }^{19-21}$ Other risk factors for testicular cancer, such as low birth weight ${ }^{22}$ and congenital malformations of the testes, ${ }^{23}{ }^{24}$ also support a fetal origin for testicular cancer. In addition, carcinoma in situ (the precursor of both seminomas and nonseminomas) has several characteristics in common with fetal germ cells. ${ }^{25}$ The specific aetiological factors in testicular cancer are unknown, but maternal oestrogens and hormonal disrupting agents have been proposed as causal factors acting on the male fetus. ${ }^{26} 27$

\section{What is already known on this topic}

The incidence of testicular cancer has increased in the past 50 years, and some evidence suggests that sperm quality has decreased in the same period

Common aetiological factors may exist for testicular cancer and male subfertility

\section{What this study adds}

This study confirms that incidence of testicular cancer is increased in men with few children for their age

The association between testicular cancer and abnormal semen characteristics is statistically robust and consistent with the hypothesis of a common aetiology

Abnormal semen characteristics may be associated with extragonadal germ cell tumours

Table 5 Evaluation of the six cases of cancers of peritoneum and other digestive organs based on notification forms received from Danish Cancer Registry

\begin{tabular}{|c|c|c|c|c|c|c|c|c|}
\hline \multirow[b]{2}{*}{ Case } & \multirow[b]{2}{*}{$\begin{array}{c}\text { Year } \\
\text { of } \\
\text { birth }\end{array}$} & \multicolumn{3}{|c|}{ Age (years) } & \multirow[b]{2}{*}{ Topography } & \multirow[b]{2}{*}{ Morphology } & \multirow[b]{2}{*}{ Comment, based on notification forms } & \multirow{2}{*}{$\begin{array}{l}\text { Consistent with } \\
\text { extragonadal } \\
\text { germ cell } \\
\text { cancer? }\end{array}$} \\
\hline & & $\begin{array}{l}\text { At } \\
\text { semen } \\
\text { analysis }\end{array}$ & $\begin{array}{l}\text { At cancer } \\
\text { diagnosis }\end{array}$ & $\begin{array}{l}\text { At } \\
\text { death }\end{array}$ & & & & \\
\hline 1 & 1949 & 30 & 39 & 45 & 1580 Retroperitoneum & 90643 Germinoma & $\begin{array}{l}\text { Uncertain diagnosis. Died } 1994 \text { from leukaemia. } \\
\text { Notification indicates "leukaemia secondary to testicular } \\
\text { cancer" }\end{array}$ & Possibly \\
\hline 2 & 1953 & 19 & 30 & - & 1580 Retroperitoneum & $\begin{array}{l}81403 \text { Adenocarcinoma, not } \\
\text { otherwise specified }\end{array}$ & $\begin{array}{l}\text { Uncertain diagnosis. Notification form indicates: "partly } \\
\text { differentiated adenocarcinoma" as well as "extragonadal } \\
\text { germ cell tumour" and "tumour marker concentrations } \\
\text { increased" }\end{array}$ & Possibly \\
\hline 3 & 1956 & 32 & 33 & 34 & 1580 Retroperitoneum & $\begin{array}{l}80003 \text { Neoplasm unclassified, } \\
\text { malignant }\end{array}$ & $\begin{array}{l}\text { Three notifications suggest extragonadal germ cell } \\
\text { tumour }\end{array}$ & Probably \\
\hline 4 & 1926 & 52 & 68 & 68 & 1589 Peritoneum & $\begin{array}{l}99903 \text { No microscopic confirmation; } \\
\text { clinically benign tumour }\end{array}$ & Metastatic tumour of unknown origin & Unlikely \\
\hline 5 & 1948 & 29 & 35 & - & 1580 Retroperitoneum & $\begin{array}{l}90803 \text { Teratoma, malignant, not } \\
\text { otherwise specified }\end{array}$ & $\begin{array}{l}\text { Diagnosis on notification form is: "extragonadal germ } \\
\text { cell tumour" and "embryonal carcinoma." Testicular } \\
\text { biopsy samples were negative for carcinoma in situ }\end{array}$ & Probably \\
\hline 6 & 1950 & 30 & 33 & 34 & 1580 Retroperitoneum & $\begin{array}{l}88003 \text { Sarcoma, not otherwise } \\
\text { specified }\end{array}$ & Sarcoma, not otherwise specified & Unlikely \\
\hline
\end{tabular}


We also found an increased risk of cancer of the peritoneum and other digestive organs. One explanation for this association is that some of the observed cancers in this category were misclassified testicular or extragonadal germ cell tumours. Extragonadal germ cell tumours have been associated with testicular carcinoma in situ, ${ }^{28}{ }^{29}$ suggesting a common aetiology with testicular cancer.

From a public health perspective, our study provides some reassurance to men identified with abnormal semen characteristics, despite the increased relative risks. The absolute excess of cancers is about 36 cases per 32442 men followed for 297750 person years. The absolute increase in risk for the individual is therefore very small.

Contributors: RJ was responsible for the study design, data collection, statistical analysis, interpretation, and reporting and is the guarantor. $\mathrm{EB}, \mathrm{GE}, \mathrm{JH}, \mathrm{JHO}, \mathrm{NES}$, and $\mathrm{HM}$ contributed to the study design, data collection, interpretation, and reporting.

Funding: Danish Research Councils.

Competing interests: None declared.

1 Carlsen E, Giwercman A, Keiding N, Skakkebæk NE. Evidence for decreasing quality of semen during past 50 years. BMJ 1992;305:609-13. Swan SH, Elkin EP, Fenster L. Have sperm densities declined? A reanalysis of global trend data. Environ Health Perspect 1997;105:1228-32.

3 Coleman MP, Esteve J, Damiecki P, Arslan A, Renard H. Trends in cancer incidence and mortality. Lyons: International Agency for Research on Cancer, 1993. (IARC Scientific Publication No 121.)

4 Forman D, Møller H. Testicular cancer. Cancer Surv 1994;19-20:323-41.

5 Adami HO, Bergström R, Mohner M, Zatonski W, Storm H, Ekbom A, et al. Testicular cancer in nine northern European countries. Int J Cancer 1994;59:33-8.

6 James WH. Secular trends in monitors of reproductive hazard. Hum Reprod 1997;12:417-21.

7 Møller H. Trends in sex-ratio, testicular cancer and male reproductive hazards: are they connected? APMIS 1998;106:232-39.

8 Møller H, Skakkebæk NE. Risk of testicular cancer in subfertile men: case-control study. BMJ 1999;318:559-62.

9 Swerdlow AJ, Huttly SR, Smith PG. Testis cancer: post-natal hormonal factors, sexual behaviour and fertility. Int J Cancer 1989;43:549-53.

10 Jabsen R, Antoniades B, Bostofte E, Engholm G, Hansen J, Skakkebaek $\mathrm{NE}$, et al. Fertility and offspring sex ratio of men who develop testicular cancer: a record linkage study. Hum Reprod 2000;15:1958-61.

11 Bostofte E, Serup J, Rebbe H, Interrelations among the characteristics of human semen, and a new system for classification of male infertility. Fertil Steril 1989;41:95-102.
12 World Health Organization. Laboratory manual for examination of human semen and sperm-cervical mucus interaction. Cambridge: Cambridge University Press, 1999.

13 Nijman JM, Schraffordt Koops H, Kremer J, Willemse PHB, Sleijfer DT, Oldhoff J. Fertility and hormonal function in patients with nonseminomatous tumor of the testis. Arch Andrology 1985;14:239-46.

14 Carroll P, Whitmore WF Jr, Herr HW, Morse MJ, Sogani PC, Bajorunas D, et al. Endocrine and exocrine profiles of men with testicular tumors before orchidectomy. J Urol 1987;137:420-3.

15 Storm HH. The Danish Cancer Registry, a self-reporting national cancer registration system with elements of active data collection. Lyons: International Agency for Research on Cancer, 1991:220-36. (IARC Scientific Publication No 95.)

16 Bostofte E, Bagger P, Michael A, Stakemann G. Fertility prognosis for infertile men: results of follow-up study of semen analysis in infertile men from two different populations evaluated by the Cox regression model. Fertil Steril 1990;54:1100-6.

17 Coleman M, Douglas A, Hermon C, Peto J. Cohort study analysis with a Fortran computer program. Int J Epidemiol 1986;15:134-7.

18 Berthelsen JG, Skakkebæk NE. Gonadal function in men with testis cancer. Fertil Steril 1983;39:68-75.

19 Møller H. Clues to the aetiology of testicular germ cell tumours from descriptive epidemiology. Eur Urol 1993;23:8-13

20 Bergström R, Adami HO, Mohner M, Zatonski W, Storm H, Ekbom A, et al. Increase in testicular cancer incidence in six European countries: a birth cohort phenomenon. J Natl Cancer Inst 1996;88:727-33.

21 Wanderås EH, Grotmol T, Fossa SD, Tretli S. Maternal health and preand perinatal characteristics in the etiology of testicular cancer: a prospective population- and register-based study on Norwegian males born between 1967 and 1995. Cancer Causes Control 1998;9:475-86.

22 Møller H, Skakkebæk NE. Testicular cancer and cryptorchidism in relation to prenatal factors: case-control studies in Denmark. Cancer Causes Control 1997;8:904-12.

23 United Kingdom Testicular Cancer Study Group. Aetiology of testicular cancer: association with congenital abnormalities, age at puberty, infertility, and exercise. BMJ 1994;308:1393-9.

24 Møller H, Prener A, Skakkebæk NE. Testicular cancer, cryptorchidism, inguinal hernia, testicular atrophy, and genital malformations: Case control studies in Denmark. Cancer Causes Control 1995;7:264-74.

25 Skakkebæk NE, Berthelsen JG, Giwercman A, Müller J. Carcinoma-in-situ of the testis: possible origin from gonocytes and precursor of all types of germ cell tumors except spermacytoma. Int J Andrology 1987;10:19-28.

26 Sharpe RM, Skakkebaek NE. Are oestrogens involved in falling sperm counts and disorders of the male reproductive tract? Lancet $1993 ; 341: 1392-5$.

27 Henderson BE, Benton B, Jing J, Yu MC, Pike MC. Risk factors for cancer of the testis in young men. Int J Cancer 1979;23:598-602.

28 Daugaard G, Rorth M, von der Maase H, Skakkebaek NE. Management of extragonadal germ-cell tumors and the significance of bilateral testicular biopsies. Ann Oncol 1992;3:283-9.

29 Daugaard G, von der Maase H, Olsen J, Rorth M, Skakkebaek NE, Carcinoma-in-situ testis in patients with assumed extragonadal germ-cell tumours. Lancet 1987;ii:528-30.

(Accepted 19June 2000)

\title{
Towards evidence based circumcision of English boys: survey of trends in practice
}

\author{
A M K Rickwood, S E Kenny, S C Donnell
}

Department of Urology, Alder Hey Children's Hospital, Liverpool L12 2AP A M K Rickwood consultant urologist

Department of Child Health, Institute of Child Health, University of Liverpool, Alder Hey Children's

Hospital

S E Kenny

lecturer in paediatric surgery

continued over

BMJ 2000;321:792-3

\section{Introduction}

Although the proportion of English boys circumcised for medical reasons fell from 35\% in the early 1930s to $6.5 \%$ by the mid- $1980 \mathrm{~s}$, even latterly it was argued that some two thirds underwent the procedure unnecessarily, ${ }^{1}$ a judgment consistent with practice in Scandinavia, where less than $2 \%$ of boys are circumcised. ${ }^{2}$ Has any further change occurred in English practice, and, if so, is this evidence based? We examined trends in the catchment population of a children's hospital, in its surrounding region, and in England as a whole.

\section{Subjects, methods, and results}

The study was confined to medically indicated operative circumcisions. Statistics for circumcisions for the NHS, including diagnostic codings, were obtained for the Mersey region and its health districts for 1975-97 and for England for 1984-6 and 1990-8. Data for 1996-8 may slightly underestimate the number of procedures performed. ${ }^{3}$ Corresponding population figures were supplied by the Office for National Statistics. The catchment population of the Liverpool children's hospital has been taken as that of the Liverpool and Sefton health districts.

During the study period, similar proportions of procedures were indicated for phimosis in the Mersey region (89.5\%) and in England as whole (90.2\%). Rates of circumcision, overall and stratified by age, are shown in the figure. During the earlier years these rates differed little between the Mersey region and the Liverpool children's hospital, and by the mid-1980s both overall rates closely matched the figure for all 